Research Article

\title{
Impact on Yield, Biomass, Mineral Profile, pH, and Electrical Conductivity of Cherry Tomato Fruit Using a Nutrient Solution and a Silicon-Based Organomineral Fertilizer
}

\author{
Jesus Bautista, ${ }^{1}$ Fanny Hernández-Mendoza, ${ }^{2}$ and Víctor García-Gaytán ${ }^{1}{ }^{1,2,3}$ \\ ${ }^{1}$ Department of Horticulture, University of Georgia, 2360 Rainwater Road, Tifton, GA 31793, USA \\ ${ }^{2}$ Colegio de Postgraduados, Campus Montecillo, Carretera México-Texcoco km 36.5, Montecillo 56230, Texcoco, \\ Estado de México, Mexico \\ ${ }^{3}$ Laboratorio de Análisis y Diagnóstico del Patrimonio (LADIPA), EI Colegio de Michoacán, A.C., Cerro de Nahuatzen 85, \\ La Piedad 59699, Michoacán, Mexico \\ Correspondence should be addressed to Víctor García-Gaytán; garvictan@gmail.com
}

Received 1 June 2020; Revised 4 November 2020; Accepted 7 November 2020; Published 18 November 2020

Academic Editor: Gábor Kocsy

Copyright (C) 2020 Jesus Bautista et al. This is an open access article distributed under the Creative Commons Attribution License, which permits unrestricted use, distribution, and reproduction in any medium, provided the original work is properly cited.

\begin{abstract}
Cherry tomato "Atomic Grape" belongs to the Solanaceae family, an important species due to its economic value and high nutritional content. The impact on performance, weight, and nutritional profile of root, stem/branches, and leaves using the nutrient solution (NS), alone or combined with an organomineral fertilizer (F), whether granulated or in powder form was evaluated: NS, NS + F-granulated, and NS + F-powder. Best commercial fruits were obtained with NS + F-powder. Higher weights of both fresh and dry roots were obtained with NS + F-granulated and NS + F-powder. Mineral profile showed that the root builds up mostly nitrogen and silicon. Potassium was higher in stem/branches. Carbon, calcium, and sulfur were higher in the photosynthetic organ. NS increased the $\mathrm{pH}$ of the tomato juice by $9.81 \%$ and $10.90 \%$ compared to NS + F-granulated and NS + Fpowder treatments. The organomineral fertilizer provides greater benefits due to its long-lasting effect on the soil and cherry tomato plant. In this experiment, we conclude that the combination of NS + F-powder obtained the best marketable fruits. It must be taken into consideration the greatest demand for nutrients in tomato given to developing organs such as leaves, flowers, and fruits. The leaves should be used for nutritional diagnosis, to confirm symptoms of deficiency or optimal nutritional ranges, which is of utmost importance for agronomists, growers, horticulturists, and physiologists.
\end{abstract}

\section{Introduction}

Tomato (Solanum lycopersicum) is one of the world's most commonly grown species with the highest consumption rate. Mexico is one of the leading tomato suppliers, with a $25.11 \%$ market share worldwide [1]. Tomato is usually grown using a higher content of inorganic fertilizers that are applied using broadcast fertilization with several fertigations than organic fertilizers [2]. The current global scenario strongly indicates the need to adopt eco-friendly agricultural practices for sustainable food production [3]. In comparison with traditional inorganic fertilizers, when used alone, organic fertilizers led to a lower $\mathrm{N}$ concentration in the leaves and fruit of tomatoes. The combined use of compost and inorganic fertilizer, however, produced higher yields and better fruit quality [4].

Organomineral fertilizer-treated plants result in increased fruit quality and yield and increased activity of antioxidant enzymes [5]. Studies suggest that organomineral fertilizer inhibits $\mathrm{Na}$ accumulation and proline increase in the leaves and it is considered to alleviate salinity stress [6].

In comparison with conventional organic fertilizers, organomineral fertilizers have the potential to improve soil structure more. For example, Nguyen et al. [7] noted that organomineral biochar fertilizer results in agronomic advantages because farmers put a higher concentration of nutrients into the soil without limiting $\mathrm{N}$ availability, or $\mathrm{N}$ uptake. However, it is notable that the purpose of an organic 
production system is the support and sustainability of healthy ecosystems, soil, farmers, food production, communities, and economies [3]. The combined application of organomineral and inorganic fertilizers has resulted in the best okra performance [8]. In one study, in comparison with the control, organomineral fertilizer on $10 \mathrm{t}$ ha and $5 \mathrm{t} \mathrm{ha}^{-1}$ increased fruit yield by 53.49 and $15.93 \%$, respectively. Furthermore, the effect of drought stress can be reduced by using organomineral fertilizer as a soil amendment for vegetable crops [9]. In another study, to grow $1 \mathrm{~kg}$ of cherry tomato, $41 \mathrm{~L}^{-1}$ of a nutrient solution was required using subirrigation (closed system), and $59 \mathrm{~L}^{-1}$ of a nutrient solution was required using drip-irrigation (open system) [10]. The best substrate for cherry tomato is zeolite, which is probably related to its high water-holding capacity and cation exchange capability [11]. The relatively higher electric conductivity (EC) in the nutrient solution increases metabolite content which is beneficial for human health [12]. The application of water and nutrients through fertigation is used in commercial and horticultural agriculture to produce high yield/high-quality fruits and vegetables [13]. The main objective of this work was to evaluate the effect that a nutritive solution alone or in combination with an organomineral fertilizer (granulated and powdered) had on the plant development parameters, yield and nutritional profile of the cherry tomato.

\section{Materials and Methods}

2.1. Experiment Site. The experiment was carried out in El Colegio de Michoacan (COLMICH) in La Piedad, Michoacan, Mexico. The experimental site was located $20^{\circ} 21^{\prime}$ Latitude $\mathrm{N}$ and $102^{\circ} 02^{\prime}$ Longitude $\mathrm{W}$ with an average altitude of 1680 m.s.a.l. It is a Public Research Center of the National Council of Science and Technology (CONACYT). The experiment was conducted from January to April 2020.

\subsection{Plant Material, Growing Conditions, Treatments, and} Experimental Design. Cherry tomato "Atomic Grape" was used in this study. Seedlings were taken out from the nursery trays. Roots were removed from the substrate with running water. The experimental unit consisted of $2 \mathrm{~kg}$ capacity pots. The experimental design was completely random blocks. Treatments consisted of a granulated organomineral fertilizer (F-granulated) and powder (Fpowder), plus control (NS). NS was applied alone and combined with the formulated fertilizer. Four replicates per treatment were used. Organomineral fertilizer has a longacting effect with the following formula (Silifosca ${ }^{\circledR}$ ): $20.0 \%$ $\mathrm{SiO}_{2}, 13 \% \mathrm{P}_{2} \mathrm{O}_{2}, 1.0 \% \mathrm{~K}_{2} \mathrm{O}, 16.50 \% \mathrm{CaO}, 1.20 \% \mathrm{MgO}, 1.0 \%$ $\mathrm{ZnO}$, and $6.50 \% \mathrm{FeO}$. Supplied NS consisted of meq $\mathrm{L}^{-1}$ of $\mathrm{Ca}(\mathrm{NO} 3)_{2}, \mathrm{KNO} 3$, and $\mathrm{MgSO} 4$, which were applied every 48 hours.

2.3. SPAD Index, Yield, and Fresh and Dry Weights of Roots, Leaves, and Stem/Branches in Tomato. The SPAD index was obtained from mature leaves using SPAD portable equipment (502 Konica Minolta, Osaka, Japan). The values represent the average of the three replicates. Fruit yield was determined by weighing the fruits of each one of the plants. To determine the fresh weight, all roots, leaves, and stems/branches of each one of the plants were separated and weighed. Once each organ was processed, they were placed in an oven at $60^{\circ} \mathrm{C}$ for 72 hours to determine the dry weight.

2.4. Mineral Profile in Root, Stem/Branches, and Leaves of Tomato Plant. Biomass was quantified, and then the sample was placed in an oven (Felisa ${ }^{\circledR}$, model Fe-292 AD) at $60^{\circ} \mathrm{C}$ for 72 hours. The processing of the samples was developed according to what was described by García-Gaytán et al. [14]. Relative content was determined by using a scanning electron microscope (SEM) (Scanning Electron Microscope, Model 7582, England), equipped with energy-dispersive spectroscopy (EDS).

\subsection{Electrical Conductivity (EC) and $p H$ of Tomato Fruit.} Fruits were combined in a blender, and strained juice was filtered using a $110 \mathrm{~mm}$ diameter paper filter $\left(\right.$ Whatman $^{\mathrm{TM}}$ ). EC was expressed in $\mathrm{dS} \cdot \mathrm{m}^{-1}$, and $\mathrm{pH}$ was determined using Thermo Fisher Scientific Inc. (Orion Star ${ }^{\mathrm{TM}}$ A215, Multiparameter). The juice was used for both analyses.

\section{Data Analysis}

Data were analyzed using the statistical software SAS ver. 9.3. We carried out a variance analysis (PROC ANOVA). Means comparison was done using Tukey's test with a significance value of $95 \%(P \leq 0.05)$, in order to determine significant differences among treatments.

\section{Results}

4.1. SPAD Index, Yield, and Fresh and Dry Weights of Root, Leaf, and Stem/Branches. There were no significant differences in the SPAD index with the NS and organomineral fertilizer (Table 1). There were no statistically significant differences in the fresh weight of the fruit between treatments. $\mathrm{SN}+\mathrm{F}$-granulated treatment increased root fresh weight (RFW) by $12.29 \%$, compared to $\mathrm{SN}+\mathrm{F}$-powder treatment. Leaf fresh weight (LFW) and fresh stem/branch weight (S/BFW) increased significantly by $63.79 \%$ and $48.82 \%$ with NS + F-powder, compared to control (Table 1). The fruits from our experiment showed good commercial characteristics using a combined NS and organomineral fertilizer (Figure 1).

Statistical analysis showed that there were no significant statistical differences for root dry weight and stem/branch dry weight. In the case of the leaf dry weight variables, there were highly significant differences $(P \leq 0.001)$ with the $\mathrm{NS}+\mathrm{F}$-powder treatment (Table 2). Root, leaves, and stem/ branch weights are important decisive factors for crop performance. The highest values in this study were obtained with the combination of NS and organomineral fertilizer (Tables 1 and 2). 
TABLE 1: Effect of NS and organomineral fertilizer on chlorophyll and fresh weight in cherry tomato.

\begin{tabular}{lccccc}
\hline Treatment & Chlorophyll content (SPAD index) & FFW (g-plant) & RFW (g-plant) & LFW (g-plant) & S/BFW (g-plant) \\
\hline NS & $40.83 \pm 11.1 \mathrm{a}$ & $25.93 \pm 25.4 \mathrm{a}$ & $5.02 \pm 0.7 \mathrm{~b}$ & $8.07 \pm 2.6 \mathrm{~b}$ & $31.65 \pm 11.9 \mathrm{ab}$ \\
NS + F-granulated & $41.57 \pm 6.63 \mathrm{a}$ & $22.54 \pm 16.23 \mathrm{a}$ & $9.682 .71 \mathrm{a}$ & $10.41 \pm 3.99 \mathrm{~b}$ & $27.96 \pm 6.74 \mathrm{~b}$ \\
NS + F-powder & $39.25 \pm 4.56 \mathrm{a}$ & $46.80 \pm 11.26 \mathrm{a}$ & $8.49 \pm 1.93 \mathrm{ab}$ & $28.75 \pm 8.02 \mathrm{a}$ & $54.64 \pm 15.65 \mathrm{a}$ \\
CV & 19.54 & 58.51 & 25.52 & 34.18 & 31.55 \\
$P$ value & 0.09 & 2.00 & $6.02^{* * *}$ & $17.70^{* *}$ & $5.79^{* *}$ \\
\hline
\end{tabular}

Means followed by different letters in each column indicate significant differences among treatments $\left({ }^{* * *} P \leq 0.001 ;{ }^{* *} P \leq 0.01\right)$. RFW = root fresh weight; $\mathrm{FFW}=$ fresh fruit weight; FLW = fresh leaf weight; $\mathrm{S} / \mathrm{BFW}=$ fresh stem/branch weight; $\mathrm{CV}=$ coefficient of variation.

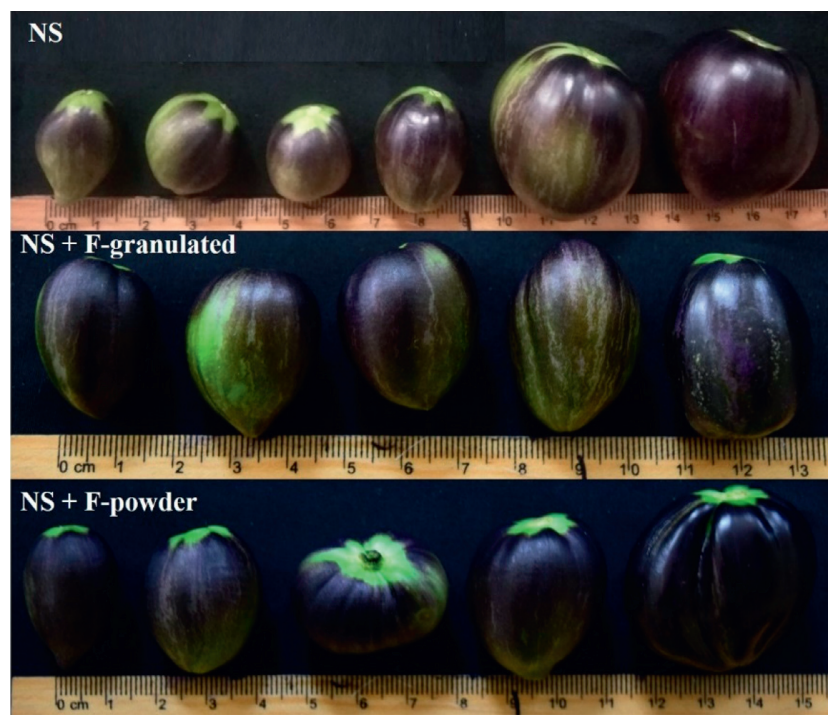

FIgURE 1: Characteristics of the cherry tomato "Atomic Grape" by the effect of the NS, F-granulated, and F-powder.

TABLE 2: Effect of NS and organomineral fertilizer on dry weight in cherry tomato.

\begin{tabular}{lccc}
\hline Treatment & RDW (g-plant) & LDW (g-plant) & S/BDW (g-plant) \\
\hline NS & $0.73 \pm 0.38 \mathrm{a}$ & $2.29 \pm 0.83 \mathrm{~b}$ & $5.31 \pm 2.50 \mathrm{a}$ \\
NS + F-granulated & $1.02 \pm 0.30 \mathrm{a}$ & $3.05 \pm 0.10 \mathrm{~b}$ & $3.84 \pm 1.16 \mathrm{a}$ \\
NS + F-powder & $1.17 \pm 0.12 \mathrm{a}$ & $7.02 \pm 0.36 \mathrm{a}$ & $7.80 \pm 2.22 \mathrm{a}$ \\
CV & 30.12 & 13.33 & 3.82 \\
$P$ value & 2.27 & $85.23^{* * *}$ & 36.18 \\
\hline
\end{tabular}

Means followed by different letters in each column indicate significant differences among treatments $\left({ }^{* * *} P \leq 0.001 ;{ }^{* *} P \leq 0.01\right)$. RDW = root dry weight; $\mathrm{LDW}=$ leaf dry weight; $\mathrm{S} / \mathrm{BDW}=$ stem/branch dry weight; $\mathrm{CV}=$ coefficient of variation.

4.2. Mineral Profile in Root, Stem/Branches, and Leaves of Tomato. Table 3 shows the multielement profile in the root, stem/branches, and leaves. In the root, an organ of uptake and transport of nutrients, a higher concentration of $\mathrm{N}(P \leq 0.01), \mathrm{Na}, \mathrm{Si}$, and $\mathrm{Al}(P \leq 0.001)$ was found, whereas in stem/branches $\mathrm{O}, \mathrm{K}$, and $\mathrm{Cl}(P \leq 0.001)$ were primarily found (Table 3 ). In leaves, a photosynthetic organ, mainly $\mathrm{C}, \mathrm{Ca}$, and $\mathrm{S}(P \leq 0.001)$ were found compared to root stem/branches.

4.3. Effect of Organomineral Fertilizer on Nutrient Concentration in Tomato Plants. Statistical analysis showed that the concentration of $\mathrm{O}, \mathrm{N}, \mathrm{Ca}$, and $\mathrm{Si}$ was higher when applying NS (Table 4). This may be due to the fact that NS contained soluble fertilizers $\left(\mathrm{Ca}\left(\mathrm{NO}_{3}\right)_{2}, \mathrm{KNO}_{3}\right.$, and $\left.\mathrm{MgSO}_{4}\right)$. A slight increase in $\mathrm{Fe}$ was observed when $\mathrm{NS}+\mathrm{F}$-granulated was added to the pots.

The values of nutrient concentration using the organomineral fertilizer were similar to those of the NS, maybe due to its prolonged action in the soil (Table 4). For example, the organomineral fertilizer is rich in Si (20\%), but the treatment was less than the NS, probably because the highest concentration of Si was taken up by and built up in the roots (Table 3).

4.4. Determination of $p H$ and EC of Tomato Fruit Juice. Figures 2(a) and 2(b) show the $\mathrm{pH}$ and $\mathrm{EC}$ values of tomato fruit juice, respectively. NS increased the $\mathrm{pH}$ of the tomato juice by $9.81 \%$ and $10.90 \%$ compared to NS + F-granulated and NS + F-powder. The pH ranges were 5.5, 4.96, and 4.90, 
TABLE 3: Nutrient profile in the root, stem/branches, and leaves of cherry tomato.

\begin{tabular}{|c|c|c|c|c|c|}
\hline Mineral nutrients & Root & Stem/branches & Leaves & $\mathrm{CV}$ & $P$ value \\
\hline C (\%) & $46.29 \pm 2.41 b$ & $46.26 \pm 2.20 \mathrm{~b}$ & $48.16 \pm 1.41 \mathrm{a}$ & 2.75 & $6.41^{* * *}$ \\
\hline O (\%) & $41.21 \pm 1.45 b$ & $43.56 \pm 0.34 a$ & $39.59 \pm 0.69 c$ & 1.25 & $133.63^{* * *}$ \\
\hline N (\%) & $2.97 \pm 0.30 \mathrm{a}$ & $1.29 \pm 1.54 b$ & $1.85 \pm 1.43 \mathrm{ab}$ & 50.54 & $6.17^{* *}$ \\
\hline $\mathrm{P}(\%)$ & $0.22 \pm 0.08 \mathrm{a}$ & $0.22 \pm 0.08 \mathrm{a}$ & $0.29 \pm 0.05 a$ & 29.13 & 2.70 \\
\hline K (\%) & $1.86 \pm 0.11 \mathrm{c}$ & $3.53 \pm 0.45 \mathrm{a}$ & $2.31 \pm 0.26 b$ & 7.24 & $192.64^{* * *}$ \\
\hline $\mathrm{Ca}(\%)$ & $1.68 \pm 0.31 c$ & $2.03 \pm 0.49 b$ & $2.44 \pm 0.25 a$ & 9.94 & $31.07^{* * *}$ \\
\hline $\operatorname{Mg}(\%)$ & $0.62 \pm 0.07 \mathrm{a}$ & $0.44 \pm 0.12 b$ & $0.72 \pm 0.05 a$ & 13.60 & 27.22 \\
\hline S (\%) & $0.45 \pm 0.12 b$ & $0.15 \pm 0.09 c$ & $0.94 \pm 0.10 \mathrm{a}$ & 17.21 & $182.44^{* * *}$ \\
\hline $\mathrm{Na}(\%)$ & $0.75 \pm 0.15 a$ & $0.36 \pm 0.10 \mathrm{~b}$ & $0.31 \pm 0.08 \mathrm{~b}$ & 22.60 & $45.45^{* * *}$ \\
\hline $\mathrm{Cl}(\%)$ & $0.77 \pm 0.09 b$ & $1.33 \pm 0.15 \mathrm{a}$ & $0.88 \pm 0.13 b$ & 12.57 & $50.08^{* * *}$ \\
\hline Si (\%) & $2.20 \pm 0.87 \mathrm{a}$ & $0.51 \pm 0.16 \mathrm{c}$ & $1.68 \pm 0.24 b$ & 10.72 & $270.00^{* * *}$ \\
\hline $\mathrm{Fe}(\mathrm{ppm})$ & $0.34 \pm 0.09 a$ & $0.09 \pm 0.13 b$ & $0.31 \pm 0.10 \mathrm{a}$ & 32.06 & 26.49 \\
\hline $\mathrm{Al}(\mathrm{ppm})$ & $0.56 \pm 0.09 \mathrm{a}$ & $0.17 \pm 0.05 c$ & $0.45 \pm 0.08 \mathrm{~b}$ & 15.37 & $99.39^{* * *}$ \\
\hline
\end{tabular}

Means followed by different letters in each column indicate significant differences among treatments $\left({ }^{* * *} P \leq 0.001 ;{ }^{* *} P \leq 0.01\right)$. CV $=$ coefficient of variation.

TABLE 4: Nutrient profile due to the effect of NS and organomineral fertilizer in tomato cherry.

\begin{tabular}{|c|c|c|c|c|c|}
\hline Mineral nutrients & NS & NS + F-granulated & NS + F-powder & $\mathrm{CV}$ & $P$ value \\
\hline C (\%) & $44.82 \pm 1.73 b$ & $47.43 \pm 1.47 \mathrm{a}$ & $48.47 \pm 1.49 \mathrm{a}$ & 2.75 & 19.11 \\
\hline O (\%) & $42.18 \pm 1.61 \mathrm{a}$ & $41.21 \pm 1.95 b$ & $40.97 \pm 2.08 b$ & 1.25 & $13.67^{* * *}$ \\
\hline N (\%) & $2.60 \pm 1.04 \mathrm{a}$ & $2.23 \pm 1.30 \mathrm{ab}$ & $1.28 \pm 1.53 b$ & 50.54 & $3.92^{* *}$ \\
\hline $\mathrm{P}(\%)$ & $0.24 \pm 0.11 \mathrm{a}$ & $0.26 \pm 0.06 a$ & $0.24 \pm 0.05 a$ & 29.13 & 0.19 \\
\hline K (\%) & $2.65 \pm 1.07 \mathrm{a}$ & $2.50 \pm 0.71 \mathrm{a}$ & $2.56 \pm 0.53 a$ & 7.24 & 1.48 \\
\hline $\mathrm{Ca}(\%)$ & $2.34 \pm 0.31 \mathrm{a}$ & $1.99 \pm 0.38 \mathrm{~b}$ & $1.82 \pm 0.57 b$ & 9.94 & $15.27^{* * *}$ \\
\hline $\operatorname{Mg}(\%)$ & $0.62 \pm 0.07 \mathrm{a}$ & $0.55 \pm 0.16 \mathrm{a}$ & $0.60 \pm 0.18 \mathrm{a}$ & 13.60 & 1.48 \\
\hline S (\%) & $0.55 \pm 0.32 \mathrm{a}$ & $0.45 \pm 0.33 a$ & $0.54 \pm 0.42 a$ & 17.21 & 0.03 \\
\hline $\mathrm{Na}(\%)$ & $0.44 \pm 0.17 \mathrm{a}$ & $0.46 \pm 0.25 \mathrm{a}$ & $0.52 \pm 0.28 \mathrm{a}$ & 22.60 & 1.16 \\
\hline $\mathrm{Cl}(\%)$ & $1.02 \pm 0.36 \mathrm{a}$ & $0.98 \pm 0.24 \mathrm{a}$ & $0.99 \pm 0.25 a$ & 12.57 & 0.25 \\
\hline Si (\%) & $1.88 \pm 1.21 \mathrm{a}$ & $1.21 \pm 0.43 b$ & $1.30 \pm 0.74 b$ & 10.72 & $48.55^{* * *}$ \\
\hline $\mathrm{Fe}(\mathrm{ppm})$ & $0.18 \pm 0.15 b$ & $0.30 \pm 0.0 \mathrm{a}$ & $0.26 \pm 0.20 \mathrm{ab}$ & 32.06 & $5.10^{* *}$ \\
\hline $\mathrm{Al}(\mathrm{ppm})$ & $0.42 \pm 0.24 \mathrm{a}$ & $0.35 \pm 0.13 \mathrm{a}$ & $0.40 \pm 0.18 \mathrm{a}$ & 15.37 & 2.54 \\
\hline
\end{tabular}

Means followed by different letters in each column indicate significant differences among treatments $\left({ }^{* * *} P \leq 0.001\right.$; $\left.^{* *} P \leq 0.01\right)$. $\mathrm{CV}=$ coefficient of variation.

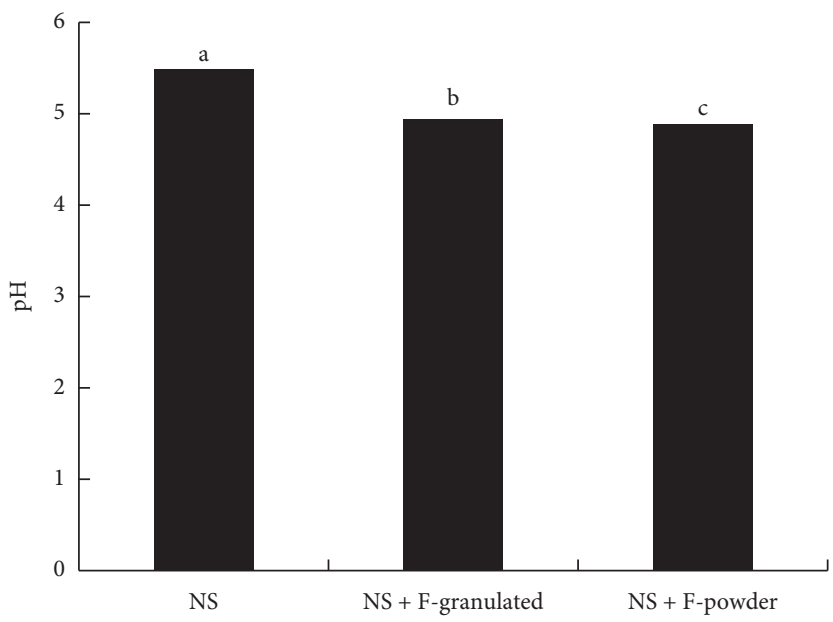

(a)

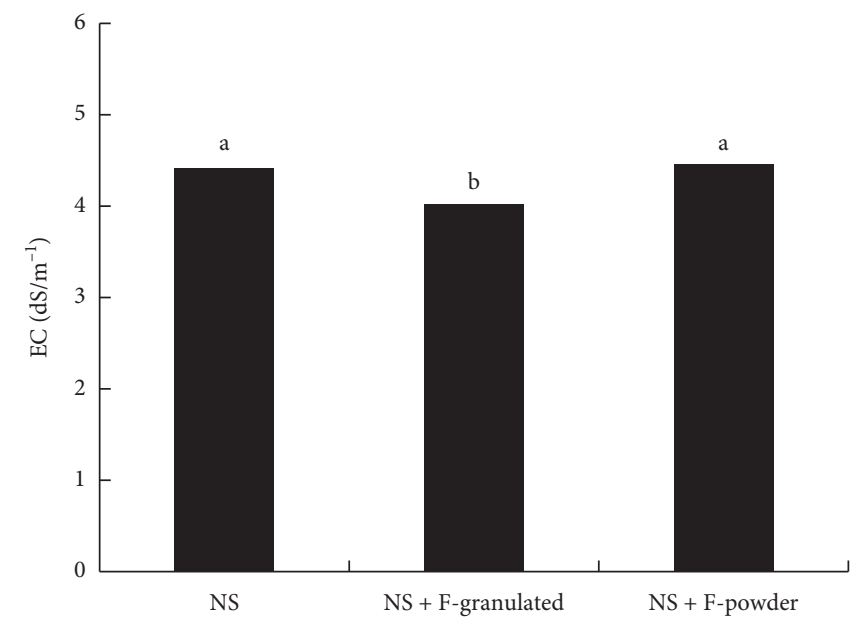

(b)

Figure 2: Effect of variations in NS, NS + F-granulated, and NS + F-powder on $\mathrm{pH}$ and electrical conductivity $(\mathrm{EC})$ values $\left(\mathrm{dS} \cdot \mathrm{m}^{-1}\right)$ of tomato cherry fruit. Data shown represent an average of nine replicates. Different letters represent significance according to Tukey's test $\left({ }^{* *} P \leq 0.05\right)$. 
respectively (Figure 2(a)). No statistically significant differences were found for EC in tomato juice. The EC ranges in the treatments were $4.43,4.02$, and $4.46\left(\mathrm{dS} \cdot \mathrm{m}^{-1}\right)$ (Figure 2(b)).

\section{Discussion}

Table 1 shows that fresh root weight (RFW) increased by $12.29 \%$ with the $\mathrm{SN}+\mathrm{F}$-granulated treatment, while with $\mathrm{NS}+\mathrm{F}$-powder treatment, leaf fresh weight (LFW) and fresh stem/branch weight (S/BFW) increased significantly by $63.79 \%$ and $48.82 \%$, respectively (Table 1 ). The fruits showed good commercial characteristics using a combined NS and organomineral fertilizer (Figure 1). Heeb et al. [15] published yields of red tomatoes from organically fertilized plants that were significantly lower than yields from plants that received mineral fertilizer (nutrient solutions). On the other hand, Tonfack et al. [16] determined that the application of organic fertilizer, mineral fertilizer, or a combination of both significantly improved plant development and increased the number of trusses and fruits per plant and commercially available fruits in two tomato varieties.

An integrated plant nutrient system (a combination of organic and inorganic fertilizers) is suitable for improving growth, yield, and number of roots in cabbage [17]. For the tomatoes, a higher number of fruits per plant and plant height were obtained from mixed fertilizers (organic and inorganic) than from the other treatments [3]. A study by Herencia et al. [18] found that crop yield was not significantly different between treatments using organic vs. mineral fertilization. Geneticists and plant breeders are focusing their studies on developing plants with roots that improve crop productivity under drought conditions [19]. Therefore, roots need to develop continuously to reach new soil sectors that are high in P [20]. In addition, this can be induced by good control of nutrient solution, stimulants, and root bioprotection (fungi and bacteria) in fertigation programs [21].

Plants uptake and translocate nutrients from the root to the conducting vessels (xylem and phloem). Nutrients are redistributed to the entire system, and in the case of the tomato, the greatest demand for nutrients is given to developing organs such as leaves, flowers, and fruits.

In this experiment, we observed that $\mathrm{N}, \mathrm{Na}, \mathrm{Si}$, and $\mathrm{Al}$ $(2.97>2.20>0.75>0.56 \%$, ppm, respectively) were mainly accumulated in roots. $\mathrm{O}, \mathrm{K}$, and $\mathrm{Cl}(43.56>3.53>1.33 \%$, respectively) were mostly accumulated in stem/branches. C, $\mathrm{Ca}$, and $\mathrm{S}(48.16>2.44>0.94 \%$, respectively) were accumulated in the leaves. There were no statistically significant differences between organs for the accumulation of $\mathrm{P}, \mathrm{Mg}$, and Fe (Table 3).

The tomato leaf is one of the main organs used for nutritional diagnosis, to confirm either symptoms of deficiency or optimal nutritional ranges. Primary and secondary macronutrients are responsible for the development of biomass and fruit quality.

In some cases, macronutrients were higher in roots and stems than in other plant parts (Table 3). The leaf $\mathrm{N}$ concentration was below the reported optimal range [22].
However, the $\mathrm{P}, \mathrm{K}, \mathrm{Ca}, \mathrm{Mg}$, and $\mathrm{S}$ in the leaves were within the optimal ranges reported (Table 3 ). The nutrient levels recorded in tomato leaves during the harvest period were $0.4 \% \mathrm{P}, 2.5 \% \mathrm{~K}, 2.0 \% \mathrm{Ca}, 0.5 \% \mathrm{Mg}$, and $0.6 \% \mathrm{~S}$ [22]. Nutrients such as $\mathrm{Ca}$ and $\mathrm{Mg}$ have a positive effect on growth, biomass partitioning, and fruit production [23]. Organomineral fertilizer in this study provides nutrients such as $\mathrm{Ca}$, $\mathrm{K}$, and $\mathrm{Mg}$, as well as the nutrient solution. In fruits and vegetables, the ratios of $\mathrm{Mg}$ to other nutrients, such as $\mathrm{Ca}$ and $\mathrm{K}$, were shown to be a more reliable indicator of the quality response [24]. When plant roots acquire readily available nutrients from the soil solution, they are rapidly absorbed. The NS treatment with soluble fertilizers had a significant effect on $\mathrm{O}, \mathrm{N}$, and $\mathrm{Ca}$ (Table 4), but it also influenced the uptake of $\mathrm{Si}$ (Table 4). In tomatoes, $\mathrm{NH}_{4} \mathrm{NO}_{3}$ supplementation increased $\mathrm{N}$ in the leaves. Supplemental $\mathrm{K}$ increased $\mathrm{N}$ and $\mathrm{K}$ in the leaves [25].

Organomineral fertilizers were used as amendments and for soil improvements. The slow release of nutrients may have resulted in nutritional deficiencies and physiological problems in the tomato fruits.

For example, a study by Yanar et al. [26] showed that fruit cracking rates were higher in organic fertilizer treatments than in inorganic fertilizer treatments. The organomineral fertilizer used in this research had macro- and micronutrients, except N. However, organomineral fertilizers can be enriched by adding raw materials to increase their nutrient levels. For example, Youssef and Eissa [27] found that in comparison with the control, mixing rabbit manure, rock phosphate, and feldspar plus biofertilizer inoculation increased the concentration of $\mathrm{N}, \mathrm{P}$, and $\mathrm{K}$ in the leaves of tomato by $34 \%, 35 \%$, and $50 \%$, respectively.

Table 4 shows that there were no significant differences in $\mathrm{P}, \mathrm{K}, \mathrm{Mg}, \mathrm{S}, \mathrm{Na}, \mathrm{Cl}$, and $\mathrm{Al}$. Both the application of NS and its combinations (granulated and powder) presented the same values (Table 4 ). This indicates that they present the same effectiveness in tomato nutrition (Table 4). In highly degraded soils such as oxisols, organomineral phosphate fertilizers are as effective as conventional water-soluble $\mathrm{P}$ fertilizers such as triple superphosphate [28]. In comparison with mineral fertilizers, organic fertilizers released nutrients more slowly, resulting in decreased $\mathrm{S}$ and $\mathrm{P}$ concentrations in the leaves [15]. Tonfack et al. [16] observed that the application of organic fertilizer, mineral fertilizer, or a combination of both significantly improved the content of $\mathrm{P}$, $\mathrm{K}, \mathrm{Ca}$, and $\mathrm{Na}$ in the fruit. A study by Herencia et al. [18] showed that the use of organic fertilizer rather than other fertilizers resulted in higher soil organic matter, soil $\mathrm{N}$ content, and available $\mathrm{P}$ and K. Ordóñez-Santo et al. [29] observed differences in the micronutrient content in organic and conventional tomatoes. Research carried out by Nascimiento et al. [30] showed that the release of nutrients in granular organomineral fertilizers was not affected by different binder materials.

In Figure 2, there are significant differences $(P \leq 0.001)$ in the $\mathrm{pH}$ of tomato juice. The highest $\mathrm{pH}$ was found with NS, and the increase was $9.81 \%$ and $10.90 \%$ with respect to the granulated fertilizer and powder, respectively. There were no significant differences in EC (Figure 2). Moya et al. 
[12] observed that the EC and $\mathrm{pH}$ of tomato juice showed nonsignificant differences due to the effect of EC in the nutrient solution. In accordance with Tzortzakis and Economakis [31], the $\mathrm{pH}$ and $\mathrm{EC}$ of tomato fruit juice were not significantly different in tomato cultivation with different substrates. The $\mathrm{pH}$ obtained was 4 , and the $\mathrm{EC}$ was $3 \mathrm{dS} \cdot \mathrm{m}^{-1}$. Youssef and Eissa [27] showed that the $\mathrm{pH}$ and EC of tomato juice had the highest values with the control treatment (conventional fertilization).

\section{Conclusion}

Cherry tomato "Atomic Grape" is a gourmet fruit of great economic importance. Organomineral fertilizer improves soil and increases the nutrition of tomato plants. Organomineral fertilizers sometimes do not contain some essential elements. Therefore, it is necessary to supply with other inorganic sources. In this experiment, it was shown that of the treatments, the combination of NS + F-powder obtained the best marketable fruits. The fresh and dry biomass obtained with NS + F-granulated and NS + powder was highest. $\mathrm{N}, \mathrm{Na}, \mathrm{Si}$, and $\mathrm{Al}$ were mainly accumulated in roots. $\mathrm{O}, \mathrm{K}$, and $\mathrm{Cl}$ were mainly accumulated in stems/branches. $\mathrm{C}, \mathrm{Ca}$, and $\mathrm{S}$ were mainly accumulated in the leaves. The tomato leaf is one of the main organs for nutritional diagnosis. In leaves, $\mathrm{P}, \mathrm{K}, \mathrm{Ca}, \mathrm{Mg}$, and $\mathrm{S}$ were within their optimal ranges. The application of the NS and its combinations (granulated and powder) presented the same effectiveness for the concentrations of $\mathrm{P}, \mathrm{K}, \mathrm{Mg}, \mathrm{S}, \mathrm{Na}, \mathrm{Cl}$, and $\mathrm{Al}$. In comparison with the NS + F-granulated and NS + F-powder treatments, the NS treatment increased the $\mathrm{pH}$ of the tomato juice.

\section{Data Availability}

The data used to support the findings of the study are available from the corresponding author upon request.

\section{Conflicts of Interest}

The authors declare that they have no conflicts of interest regarding authorship and publication of this paper.

\section{Acknowledgments}

The authors thank El Colegio de Michoacán y el Laboratorio de Análisis y Diagnóstico del Patrimonio (LADIPA) and also Ing. Esteban Sánchez and M.C. Luis R. Velázquez for the support provided.

\section{References}

[1] SAGARPA Secretaría de Agricultura, Ganadería, Desarrollo Rural, Pesca y alimentación, "Planeación agrícola nacional 2017-2030. Jitomate mexicano," 2016, https://www.gob.mx/ cms/uploads/attachment/file/257077/Potencial-Jitomate.pdf.

[2] G. Brunetti, A. Traversa, F. De Mastro, and C. Cocozza, "Short term effects of synergistic inorganic and organic fertilization on soil properties and yield and quality of plum tomato," Scientia Horticulturae, vol. 252, pp. 342-347, 2019.

[3] M. A. Islam, S. Islam, A. Akter, M. H. Rahman, and D. Nandwani, "Effect of organic and inorganic fertilizers on soil properties and the growth, yield and quality of tomato in Mymensingh, Bangladesh," Agriculture, vol. 7, no. 18, pp. 1-7, 2017.

[4] T. Hernández, C. Chocano, J.-L. Moreno, and C. García, "Towards a more sustainable fertilization: combined use of compost and inorganic fertilization for tomato cultivation," Agriculture, Ecosystems \& Environment, vol. 196, pp. 178-184, 2014.

[5] M. M. Rady, "A novel organo-mineral fertilizer can mitigate salinity stress effects for tomato production on reclaimed saline soil," South African Journal of Botany, vol. 81, pp. 8-14, 2012.

[6] K. Kataoka, K. Sugimoto, H. Ohashi, and H. Yamada, "Effect of organo-mineral fertilizer on tomato fruit production and incidence of blossom-end rot under salinity," The Horticulture Journal, vol. 86, no. 3, pp. 357-364, 2017.

[7] T. T. N. Nguyen, H. M. Wallace, C.-Y. Xu et al., "Short-term effects of organo-mineral biochar and organic fertilisers on nitrogen cycling, plant photosynthesis, and nitrogen use efficiency," Journal of Soils and Sediments, vol. 17, no. 12, pp. 2763-2774, 2017.

[8] J. O. Olaniyi, W. B. Akanbi, O. A. Olaniran, and O. T. Ilupeju, "The effect of organo-mineral and inorganic fertilizers on the growth, fruit yield, quality and chemical compositions of okra," Journal of Animal \& Plant Sciences, vol. 9, no. 1, pp. 1135-1140, 2010.

[9] T. A. A. El-Mageed and W. M. Semida, "Organo mineral fertilizer can mitigate water stress for cucumber production (Cucumis sativus L.)," Agricultural Water Management, vol. 159, pp. 1-10, 2015.

[10] P. Santamaria, G. Campanile, A. Parente, and A. Elia, "Subirrigation vs drip-irrigation: effects on yield and quality of soilless grown cherry tomato," The Journal of Horticultural Science and Biotechnology, vol. 78, no. 3, pp. 290-296, 2003.

[11] A. Al-Ajmi, G. Al-Karaki, and Y. Othman, "Effect of different substrates on fruit yield and quality of cherry tomato grown in a closed soilless system," International Symposium on Strategies Towards Sustainability of Protected Cultivation in Mild Winter Climate, vol. 807, pp. 491-494, 2008.

[12] C. Moya, E. Oyanedel, G. Verdugo, M. F. Flores, M. Urrestarazu, and J. E. Álvaro, "Increased electrical conductivity in nutrient solution management enhances dietary and organoleptic qualities in soilless culture tomato," HortScience, vol. 52, no. 6, pp. 868-872, 2017.

[13] S. K. Malhotra, "Water soluble fertilizers in horticultural crops-An appraisal," Indian Journal of Agricultural Science, vol. 86, no. 10, pp. 1245-56, 2016.

[14] V. García-Gaytán, E. Bojórquez-Quintal, F. HernándezMendoza, D. K. Tiwari, N. Corona-Morales, and Z. MoradiShakoorian, "Polymerized silicon $\left(\mathrm{SiO}_{2} \cdot \mathrm{nH}_{2} \mathrm{O}\right)$ in equisetum arvense: potential nanoparticle in crops," Journal of the Chilean Chemical Society, vol. 64, no. 1, pp. 4298-4302, 2019.

[15] A. Heeb, B. Lundegårdh, G. Savage, and T. Ericsson, "Impact of organic and inorganic fertilizers on yield, taste, and nutritional quality of tomatoes," Journal of Plant Nutrition and Soil Science, vol. 169, no. 4, pp. 535-541, 2006.

[16] L. B. Tonfack, A. Bernadac, E. Youmbi, V. P. Mbouapouognigni, M. Ngueguim, and A. Akoa, "Impact of organic and inorganic fertilizers on tomato vigor, yield and fruit composition under tropical andosol soil conditions," Fruits, vol. 64, no. 3, pp. 167-177, 2009.

[17] M. A. Islam, G. Ferdous, A. Akter, M. M. Hossain, and D. Nandwani, "Effect of organic, inorganic fertilizers and 
plant spacing on the growth and yield of cabbage," Agriculture, vol. 7, no. 4, pp. 1-31, 2017.

[18] J. F. Herencia, J. C. Ruiz-Porras, S. Melero, P. A. GarciaGalavis, E. Morillo, and C. Maqueda, "Comparison between organic and mineral fertilization for soil fertility levels, crop macronutrient concentrations, and yield," Agronomy Journal, vol. 99, no. 4, pp. 973-983, 2007.

[19] L. Comas, S. Becker, V. M. V. Cruz, P. F. Byrne, and D. A. Dierig, "Root traits contributing to plant productivity under drought," Frontiers in Plant Science, vol. 4, no. 442, pp. 1-16, 2013.

[20] A. Kleinert, V. Benedito, R. Morcillo et al., "Morphological and symbiotic root modifications for mineral acquisition from nutrient-poor soils,", in Root Biology, B. By Giri, R. Prasad, and A. Varma, Eds., pp. 85-142, 2018.

[21] V. García-Gaytán, F. Hernández-Mendoza, A. V. Coria-Téllez et al., "Fertigation: nutrition, stimulation and bioprotection of the root in high performance," Plants, vol. 7, no. 4, pp. 1-13, 2018.

[22] G. Hochmuth, D. Maynard, C. Vavrina, E. Hanlon, and E. Simonne, Plant Tissue Analysis and Interpretation for Vegetable Crops in Florida, UF/IFAS Extension, Gainesville, FL, USA, 2004.

[23] X. Hao and A. P. Papadopoulos, "Effects of calcium and magnesium on plant growth, biomass partitioning, and fruit yield of winter greenhouse tomato," HortScience, vol. 39, no. 3, pp. 512-515, 2004.

[24] J. Gerendás and H. Führs, “The significance of magnesium for crop quality," Plant and Soil, vol. 368, no. 1-2, pp. 101-128, 2013.

[25] M. P. N. Gent, "Effect of nitrogen and potassium supply on yield and tissue composition of greenhouse tomato," International Symposium on Growing Media and Hydroponics, vol. 644, pp. 369-375, 2001.

[26] D. Yanar, N. Gebologlu, Y. Yanar, M. Aydin, and P. Cakmak, "Effect of different organic fertilizers on yield and fruit quality of indeterminate tomato (Lycopersicon esculentum)," Scientific Research and Essays, vol. 6, no. 17, pp. 3623-3628, 2011.

[27] M. A. Youssef and M. A. Eissa, "Comparison between organic and inorganic nutrition for tomato," Journal of Plant $\mathrm{Nu}$ trition, vol. 40, no. 13, pp. 1900-1907, 2017.

[28] J. J. Frazão, V. d. M. Benites, J. V. S. Ribeiro, V. M. Pierobon, and J. Lavres, "Agronomic effectiveness of a granular poultry litter-derived organomineral phosphate fertilizer in tropical soils: soil phosphorus fractionation and plant responses," Geoderma, vol. 337, pp. 582-593, 2019.

[29] L. E. Ordóñez-Santos, M. L. Vázquez-Odériz, and M. A. Romero-Rodríguez, "Micronutrient contents in organic and conventional tomatoes (Solanum Lycopersicum L.)," International Journal of Food Science Technology, vol. 46, no. 8, pp. 1561-1568, 2011.

[30] C. O. Nascimento, B. B. Mattos, R. L. Fialho, E. C. M. CabralAlbuquerque, and V. M. Benites, "The effect of different ceramic materials to improve hardness of organomineral fertilizer granules," International Journal of Applied Ceramic Technology, vol. 17, no. 1, pp. 153-161, 2020.

[31] N. G. Tzortzakis and C. D. Economakis, "Impacts of the substrate medium on tomato yield and fruit quality in soilless cultivation," Horticultural Science, vol. 35, no. 2, pp. 83-89, 2008 . 